\title{
Benign Epithelioid Cell Type Gastrointestinal Stromal Tumor
}

National Cancer Institute

\section{Source}

National Cancer Institute. Benign Epithelioid Cell Type Gastrointestinal Stromal Tumor.

NCI Thesaurus. Code C81854.

An epithelioid cell type gastrointestinal stromal tumor with an indolent clinical course. 